\title{
Yield Components of Fodder Beet (Beta vulgaris var. crassa Mansf.) under the Middle Black Sea Region Conditions
}

\author{
Sebahattin ALBAYRAK ${ }^{1}$ \\ Necdet ÇAMAŞ ${ }^{2}$
}

Geliş Tarihi: 26.01.2006

\begin{abstract}
In this study, fodder beet growing possibilities were examined in Middle Black Sea Region. The trials were arranged in randomized complete blocks experimental designs with three replications in 2004 and 2005 growing season. Two fodder beet cultivars (Ecdogelb and Ecdorot) at 5 locations (Bafra, Ladik, Suluova, Gümüşhacıköy and Osmancık) were grown. The highest root and leaf yields were obtained from Bafra and Osmancık locations (90.6-86.9 and 13.1-12.7 $\mathrm{t} \mathrm{ha}^{-1}$, respectively). While the highest root dry matter content was determined in Ladik, Gümüşhacıköy and Suluova locations $(13.9,13.6$ and $13.3 \%$, respectively), there were not significant differences among locations (10.0-11.0 $\left.\mathrm{t} \mathrm{ha}^{-1}\right)$ except Ladik in dry matter yield. Ladik and Gümüşhacıköy locations had the highest sugar content (8.9 and $8.6 \%$, respectively). It was determined that the highest root length was in Bafra location $(23.2 \mathrm{~cm})$ and the highest root diameter was in Gümüşhacıköy location $(10.9 \mathrm{~cm})$. Bafra, Suluova, Gümüşhacıköy and Osmacık locations were determined as suitable locations for fodder beet growing, whereas Ladik location was not suitable location for fodder beet growing because of high altitude, low precipitation and low temperature.
\end{abstract}

Key Words: Fodder beet, root yield, yield components, location

\section{Orta Karadeniz Bölgesi Koşullarında \\ Yemlik Pancar (Beta vulgaris var. crassa Mansf.)' In Verim Öğeleri}

Öz: Bu çalışmada Orta Karadeniz Bölgesi'nde yemlik pancarın yetiştirilebilme olanakları araştırılmıștır. Araştırma 2004 ve 2005 yetiştirme döneminde tesadüf blokları deneme desenine göre 3 tekrarlamalı olarak kurulmuştur. Çalışmada 2 yemlik pancar çeşidi (Ecdogelb ve Ecdorot) Orta Karadeniz bölgesinde yer alan Bafra, Ladik, Suluova, Gümüşhacıköy ve Osmancık lokasyonlarında denenmiştir. Varyans analiz sonucuna göre incelenen tüm özellikler bakımından lokasyonlar arasında farklılıklar tespit edilmiştir. En yüksek yumru ve yaprak verimleri Bafra ve Osmancık lokasyonlarında (sırasıyla 90.6-86.9 ve 13.1-12.7 t ha). belirlenmiştir. En yüksek kuru madde oranı Ladik, Gümüşhacıköy ve Suluova lokasyonlarında (sırasıyla \%13.9, 13.6 ve 13.3) belirlenirken, yumru kuru madde verimleri bakımından (10.0-11.0 t ha) Ladik hariç diğer lokasyonlar arasında farklılık olmamıştır. En yüksek şeker oranı Ladik ve Gümüşhacıköy lokasyonlarında (sırasıyla, \%8.9 ve 8.6) belirlenmiştir. En yüksek yumru boyu Bafra $(23.2 \mathrm{~cm})$, en yüksek yumru çapı ise Gümüşhacıköy $(10.9 \mathrm{~cm})$ lokasyonunda belirlenmiştir. Bafra, Suluova, Gümüşhacıköy and Osmacık Orta Karadeniz bölgesinde yemlik pancar yetiştirticiliği için uygun lokasyonlar olarak belirlenirken, Ladik lokasyonu yüksek rakım düşük yağış ve düşük sıcaklıktan dolayı yemlik pancar yetiştiriciliği için uygun olmadığı tespit edilmiştir.

Anahtar Kelimeler: Yemlik pancar, yumru verimi, verim öğeleri, lokasyon

\section{Introduction}

Fodder beet offers a higher yield potential than any other "arable" fodder crop. The roots have an excellent feed quality and they are very palatable to ruminant stock. The leaf can be utilized if required to boost the total fodder output even further (Anonymous 2006). Fodder beet when grown under suitable conditions, can produce almost $20 \mathrm{t} \mathrm{ha}^{-1}$ dry matter yield (DAF, 1998) compared with $13 \pm 15 \mathrm{t} \mathrm{DM} / \mathrm{ha}^{-1}$ from four harvests of grass. Approximately $75 \%$ of fodder beet dry matter is in the root component (DAF 1998). Including fodder beet in diet of cattle increases intake of dry matter that is quantitative and qualitative factors affecting intake of the basal diet.
Vitamin and mineral supplements should be adjusted by increasing nitrogen supplements and decreasing energy from concentrate. Along with maize silage, $3 \mathrm{~kg}$ fodder beet with $5 \mathrm{~kg}$ hay per day is the optimum amount for cattle diet. It is also reported that milk contamination with butyric acid bacteria is lower when cows are fed with fodder beet compared to hay feed alone (Chenais 1994).

In this research, it was tried to determine the most suitable ecology for two fodder beet cultivars and adaptation abilities of fodder beet to climatic conditions in Middle Black Sea Region..

\footnotetext{
${ }^{1}$ Süleyman Demirel Univ. Faculty of Agriculture, Department of Agronomy-Isparta
}

${ }^{2}$ Ondokuz Mayıs Univ. Bafra Vocational School-Isparta 


\section{Material and Methods}

Fodder beet (Beta vulgaris var. crassa Mansf.) cultivars (Ecdogelb and Ecdorot which are diploid fodder beet cultivars bred at Saaten Union, Germany in 1953) were used as experimental material. Ecdogelb having wide leaf width, middle leaf length and semi erect leaf attitude, is multigerm variety. Leaf blade of Ecdogelb cultivar (width compared to length) is wide. It has also short root length and middle root width. Roots having cylindrical character are yellow. Ecdorot having wide leaf width,long leaf length and semi erect leaf attitude, is multigerm variety. Leaf blade of Ecdorot cultivar is wide. It has also short root length and wide root width. Roots having cylindrical character are red. Roots of Ecdogelb and Ecdorot cultivars grow close to surface

Field experiments were established in Bafra $\left(41^{\circ}\right.$ $35^{\prime} \mathrm{N}, 35^{\circ} 56^{\prime} \mathrm{E}, 15 \mathrm{~m}$ elevation), Osmancik (40 $58^{\circ}$ $\mathrm{N}, 34^{\circ} 51^{\prime} \mathrm{E}, 449 \mathrm{~m}$ elevation), Suluova $\left(40^{\circ} 47^{\prime} \mathrm{N}\right.$, $35^{\circ} 41^{\prime} \mathrm{E}, 484 \mathrm{~m}$ elevation), Gumushacikoy (40 $52^{\prime}$ $\mathrm{N}, 35^{\circ} 14^{\prime} \mathrm{E}, 785 \mathrm{~m}$ elevation) and Ladik (40 $56^{\circ} \mathrm{N}$, $35^{\circ} 54^{\prime} \mathrm{E}, 920 \mathrm{~m}$ elevation) in Middle Black Sea Region, Turkey, on 7-12 April 2004 and 2005 were carried out throughout the vegetation periods of the selected locations. Climatic data for the research areas are given in Table 1.

Soil types are clay loam at Bafra, Suluova and Gumushacikoy, and silty clay loam at Osmancik and Ladik.

The experimental design was a randomized complete block design with three replications and plot size was $10 \mathrm{~m}^{2}(2 \times 5 \mathrm{~m})$ and $50 \mathrm{~cm}$ row spacing. Seeding rate was $30 \mathrm{~kg} \mathrm{ha}^{-1}$. As a fertilizer, calcium ammonium nitrate (CAN) of $100 \mathrm{~kg} \mathrm{ha}^{-1}$ and triple super phosphate of $80 \mathrm{~kg} \mathrm{ha}^{-1}$ after sowing and $75 \mathrm{~kg}$ $\mathrm{ha}^{-1}$ (CAN) in May was uniformly applied to all plots. Plots were irrigated two times and three times through growing period in 2004 and 2005, respectively. There were no problems with pests, diseases or weeds during the course of study.

Ten plants from each replication were taken at harvest stage for morphological measurements. Root diameter and root length were measured from individual plants. Two square meters (duplicate $1 \mathrm{~m}^{2}$ ) area were harvested in each plot. The plots were harvested by hand after the roots matured in September and the other parameters were determined at the same time. After harvest, fresh yields of roots were determined separately and samples were dried in ovens at $70{ }^{\circ} \mathrm{C}$ to a constant weight for dry matter content. Sugar content was determined in Çarşamba sugar factory. All statistical analyses were conducted using GLM producers of SAS (1998). Means were compared using Least Significant Differences (LSD) tests at the 0.05 probability level.

\section{Results and Discussion}

The results regarding the yield components of the fodder beet cultivars under different locations are shown in Table 2. The results of variance analysis showed that there were no statistically differences among the cultivars, whereas effects of the year, location and year $x$ location interaction on root yield were significant. In 2004, the highest root yield (94.4 and $93.2 \mathrm{t} \mathrm{ha}^{-1}$ ) was obtained from Bafra and Osmancık locations, while in 2005, Bafra, Osmancık and Suluova locations had the highest yield $(86.7,80.6$ and $80.3 \mathrm{t} \mathrm{ha}^{-1}$, respectively). On average, the highest root yield was obtained in Bafra (90.6 t ha-1) and Osmancık (86.9 $\mathrm{t} \mathrm{ha}^{-1}$ ) locations; the lowest root yield was obtained in Ladik ( $\left.47.4 \mathrm{t} \mathrm{ha}^{-1}\right)$ location.

High temperature and precipitation in Bafra and Osmancik locations, comparing other locations, may cause higher root yield. As a matter of fact, Ladik location, from where the lowest root yield was obtained, had the lowest temperature and precipitation. According to previous reports, the root yield ranged from 22.59 to $145.24 \mathrm{t} \mathrm{ha}^{-1}$ in fodder beet (Buryakov 1994, Rzekanowski 1994, Stroller 1994, Koszanski et al. 1995, JuSam et al. 1995, Podstawka and Ceglarek 1995, Drashkov 1996, Grzes et al. 1996, Lukic and Vasilijevic 1996, Avcıoğlu et al. 1999, Soya et al. 1999, Naescu 2001)

Year, location and year $\mathrm{x}$ location interaction were significant for leaf yield. The lowest leaf yield was obtained from Ladik location (10.5 and $9.7 \mathrm{t}$ ha, respectively) in both years. As an average of 2 years, the highest leaf yield was obtained from Bafra and Osmancık locations (13.1 and $12.7 \mathrm{t}$ ha, respectively).

Low temperature appearing as a result of altitude and which limits plant growth in Bafra (altitude, $15 \mathrm{~m}$ ) and Osmancık (altitude, $449 \mathrm{~m}$ ) locations caused more leave yield comparing Ladik location (altitude, $920 \mathrm{~m}$ ). Research findings are similar to Adiyaman (1996) and Soya et al. (1996) who reported that leave yield was $1 / 8-1 / 10$ of root yield and this rate was equal to $10-15 t$ $\mathrm{ha}^{-1}$.

Root dry matter content was affected only by location. The highest root dry matter content was determined in Gümüşhacıköy location $(13.8 \%)$ in the first year and in Ladik location (14.6\%) in the second year. The highest root dry matter content was obtained from Ladik (13.9\%) location; the lowest root dry matter content was obtained from Bafra (11.8\%) and Osmancık (11.5\%) locations. 
ALBAYRAK, S. and N. ÇAMAŞ, "Yield components of fodder beet (Beta vulgaris var. crassa Mansf.) under

the middle black sea region conditions"

Table 1. Growing season total precipitation, mean temperature and mean humidity in the experimental areas (April through September).

\begin{tabular}{|l|l|l|l|l|l|l|l|l|l|}
\hline \multirow{2}{*}{ Locations } & \multicolumn{2}{|l|}{ Total rainfall $(\mathrm{mm})$} & \multicolumn{2}{l|}{ Mean temperature $\left({ }^{\circ} \mathrm{C}\right)$} & \multicolumn{2}{l|}{ Mean humidity $(\%)$} \\
\cline { 2 - 10 } & Long-term & 2004 & 2005 & Long-term & 2004 & 2005 & Long-term & 2004 & 2005 \\
\hline Bafra & 297 & 445 & 238 & 18.13 & 18.28 & 19.03 & 76.3 & 75.7 \\
\hline Ladik & 228 & 145 & 107 & 14.22 & 14.10 & 14.71 & 62.5 & 61.9 \\
\hline Suluova & 165 & 282 & 134 & 18.44 & 18.26 & 18.95 & 66.8 & 67.4 \\
\hline G.hacıköy & 257 & 281 & 197 & 17.79 & 17.61 & 18.52 & 52.5 & 51.3 \\
\hline Osmancık & 213 & 298 & 160 & 20.13 & 19.58 & 21.62 & 62.7 & 51.2 \\
\hline
\end{tabular}

Table 2. Results of analysis of variance of the traits determined

\begin{tabular}{|c|c|c|c|c|c|c|c|c|}
\hline $\begin{array}{l}\text { Source } \\
\text { of variance }\end{array}$ & df & Root yield & Leaf yield & $\begin{array}{l}\text { Root dry } \\
\text { matter content }\end{array}$ & $\begin{array}{l}\text { Root dry matter } \\
\text { yield }\end{array}$ & Sugar content & Root length & $\begin{array}{l}\text { Root } \\
\text { diameter }\end{array}$ \\
\hline & & $P$ & $P$ & $P$ & $P$ & $P$ & $P$ & $P$ \\
\hline \multicolumn{9}{|c|}{2004} \\
\hline Location (L) & 4 & $\star \star \star \star *$ & *** & ns & *** & ns & $\star \star \star \star *$ & 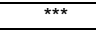 \\
\hline Block(L) & 10 & ns & ns & ns & ns & ns & * & ns \\
\hline Cultivar (C) & 1 & ns & ns & ns & ns & ns & ns & ns \\
\hline $\mathrm{L} \times \mathrm{C}$ & 4 & * & ns & ns & ns & ns & ns & ns \\
\hline CV (\%) & & 6.1 & 4.7 & 14.8 & 13.8 & 17.9 & 4.9 & 9.3 \\
\hline \multicolumn{9}{|c|}{2005} \\
\hline Location (L) & 4 & $* * *$ & $* * *$ & $* * *$ & $* * *$ & * & $* * *$ & $* * *$ \\
\hline Block(L) & 10 & ns & ns & ns & ns & ns & ** & * \\
\hline Cultivar (C) & 1 & ns & ns & ns & ns & ns & ns & ns \\
\hline $\mathrm{L} \times \mathrm{C}$ & 4 & * & ** & ns & ns & ns & ns & ns \\
\hline CV (\%) & & 9.4 & 4.8 & 6.1 & 12.5 & 17.4 & 9.1 & 7.5 \\
\hline \multicolumn{9}{|c|}{ Average of two years } \\
\hline Year $(Y)$ & 1 & $\star \star \star \star *$ & $\star * \star \star$ & ns & ns & ns & *** & ns \\
\hline Location (L) & 4 & 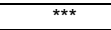 & $\star \star \star *$ & ** & $\star * \star *$ & *** & $* \star \star *$ & *** \\
\hline $\mathrm{Y} \times \mathrm{L}$ & 4 & ns & ns & ns & ns & ns & ns & ns \\
\hline Block(Yx L) & 20 & ns & ns & ns & ns & ns & *** & * \\
\hline Cultivar (C) & 1 & ns & ns & ns & ns & ns & ns & ns \\
\hline $\mathrm{Y} \times \mathrm{C}$ & 1 & ns & ns & ns & ns & ns & ns & ns \\
\hline $\mathrm{L} \times \mathrm{C}$ & 4 & $\star * \star *$ & *** & ns & ns & ns & ns & ns \\
\hline \multirow{2}{*}{\multicolumn{2}{|c|}{ CV \% }} & ns & $\mathrm{ns}$ & ns & ns & ns & ns & ns \\
\hline & & 7.8 & 4.8 & 11.1 & 13.2 & 17.7 & 7.1 & 8.5 \\
\hline
\end{tabular}

df, degrees of freedom; CV, coefficient of variation; ns, not significant. ${ }^{*} \mathrm{P}<0.05,{ }^{* *} \mathrm{P}<0.01,{ }^{* \star *} \mathrm{P}<0.001$.

Table 3. Root yield and its components of fodder beet in different locations

\begin{tabular}{|c|c|c|c|c|c|c|c|}
\hline & $\begin{array}{l}\text { Root yield } \\
\left(\mathrm{t} \mathrm{ha}^{-1}\right)\end{array}$ & $\begin{array}{l}\text { Leaf yield } \\
\left(\mathrm{t} \mathrm{ha}^{-1}\right)\end{array}$ & $\begin{array}{l}\text { Root dry matter } \\
\text { content }(\%)\end{array}$ & $\begin{array}{c}\text { Root dry matter } \\
\text { yield } \\
\left(\mathrm{t} \mathrm{ha}^{-1}\right)\end{array}$ & $\begin{array}{l}\text { Sugar content } \\
(\%)\end{array}$ & Root length $(\mathrm{cm})$ & Root diameter $(\mathrm{cm})$ \\
\hline \multicolumn{8}{|c|}{2004} \\
\hline \multicolumn{8}{|l|}{ Locations } \\
\hline Bafra & $94.4 \mathrm{a}$ & $13.9 \mathrm{a}$ & 11.2 & $10.6 \mathrm{a}$ & 6.5 & $24.7 \mathrm{a}$ & $8.8 \mathrm{~b}$ \\
\hline Ladik & $49.3 \mathrm{~d}$ & $10.5 \mathrm{c}$ & 13.3 & $6.5 \mathrm{~b}$ & 8.3 & $16.8 \mathrm{~d}$ & $7.8 \mathrm{~b}$ \\
\hline Suluova & $85.9 \mathrm{~b}$ & $12.6 \mathrm{~b}$ & 13.2 & $11.3 \mathrm{a}$ & 7.0 & $18.3 \mathrm{c}$ & $8.6 \mathrm{~b}$ \\
\hline G. hacıköy & $78.7 \mathrm{c}$ & $12.8 \mathrm{~b}$ & 13.8 & $10.8 \mathrm{a}$ & 8.8 & $19.4 \mathrm{c}$ & $11.0 \mathrm{a}$ \\
\hline Osmancık & $93.2 \mathrm{a}$ & $13.3 \mathrm{ab}$ & 11.4 & $10.6 \mathrm{a}$ & 7.6 & $23.0 \mathrm{~b}$ & $8.4 \mathrm{~b}$ \\
\hline \multicolumn{8}{|l|}{ Cultivars } \\
\hline Ecdogelb & 78.6 & 12.5 & 12.3 & 9.5 & 7.6 & 20.8 & 9.0 \\
\hline Ecdorot & 81.9 & 12.8 & 12.9 & 10.4 & 7.7 & 20.2 & 8.8 \\
\hline \multicolumn{8}{|c|}{2005} \\
\hline \multicolumn{8}{|l|}{ Locations } \\
\hline Bafra & $86.7 \mathrm{a}$ & $12.3 \mathrm{a}$ & $12.3 \mathrm{~cd}$ & $10.8 \mathrm{a}$ & $6.4 \mathrm{c}$ & $21.7 \mathrm{a}$ & $8.5 \mathrm{~b}$ \\
\hline Ladik & $45.5 \mathrm{c}$ & $9.7 \mathrm{~b}$ & $14.6 \mathrm{a}$ & $6.7 \mathrm{~b}$ & $9.7 a$ & $14.8 \mathrm{~d}$ & $7.5 \mathrm{c}$ \\
\hline Suluova & $80.3 \mathrm{ab}$ & $12.0 \mathrm{a}$ & $13.3 \mathrm{bc}$ & $10.7 \mathrm{a}$ & $7.4 \mathrm{bc}$ & $16.7 \mathrm{~cd}$ & $8.3 \mathrm{bc}$ \\
\hline G. hacıköy & $73.4 \mathrm{~b}$ & $12.2 \mathrm{a}$ & $13.5 \mathrm{~b}$ & $9.9 \mathrm{a}$ & $8.5 \mathrm{ab}$ & $18.4 \mathrm{bc}$ & $10.7 \mathrm{a}$ \\
\hline Osmancık & $80.6 \mathrm{ab}$ & $12.1 \mathrm{a}$ & $11.7 \mathrm{~d}$ & $9.4 \mathrm{a}$ & $6.9 \mathrm{bc}$ & $20.0 \mathrm{ab}$ & $7.7 \mathrm{bc}$ \\
\hline \multicolumn{8}{|l|}{ Cultivars } \\
\hline Ecdogelb & 72.7 & 11.5 & 13.1 & 9.5 & 7.7 & 18.7 & 8.8 \\
\hline Ecdorot & 74.0 & 11.8 & 13.0 & 9.5 & 7.9 & 17.9 & 8.3 \\
\hline \multicolumn{8}{|c|}{ Average of 2 years } \\
\hline \multicolumn{8}{|l|}{ Locations } \\
\hline Bafra & $90.6 \mathrm{a}$ & $13.1 \mathrm{a}$ & $11.8 \mathrm{~b}$ & $10.7 \mathrm{a}$ & $6.5 \mathrm{~b}$ & $23.2 \mathrm{a}$ & $8.7 \mathrm{~b}$ \\
\hline Ladik & $47.4 \mathrm{~d}$ & $10.1 \mathrm{c}$ & $13.9 \mathrm{a}$ & $6.6 \mathrm{~b}$ & $8.9 \mathrm{a}$ & $15.8 \mathrm{e}$ & $7.6 \mathrm{c}$ \\
\hline Suluova & $83.2 \mathrm{~b}$ & $12.3 \mathrm{~b}$ & $13.3 \mathrm{a}$ & $11.0 \mathrm{a}$ & $7.2 \mathrm{~b}$ & $17.5 \mathrm{~d}$ & $8.4 \mathrm{~b}$ \\
\hline G. hacıköy & $76.0 \mathrm{c}$ & $12.5 \mathrm{~b}$ & $13.6 \mathrm{a}$ & $10.4 \mathrm{a}$ & $8.6 \mathrm{a}$ & $18.7 \mathrm{c}$ & $10.9 a$ \\
\hline Osmancık & $86.9 \mathrm{ab}$ & $12.7 \mathrm{ab}$ & $11.5 \mathrm{~b}$ & $10.0 \mathrm{a}$ & $7.2 \mathrm{~b}$ & $21.5 \mathrm{~b}$ & $8.1 \mathrm{bc}$ \\
\hline \multicolumn{8}{|l|}{ Cultivars } \\
\hline Ecdogelb & 75.6 & 11.9 & 12.7 & 9.5 & 7.6 & 19.7 & 8.9 \\
\hline Ecdorot & 78.0 & 12.3 & 12.9 & 9.9 & 7.9 & 19.0 & 8.6 \\
\hline
\end{tabular}

Means followed by the same columns are not significantly different at $p=0.05$ leve 
Previous results indicated that there was a negative correlation between root yield and root dry matter content in fodder beet (Langer and Hill 1991, Adıyaman 1996, Geren and Avcıoğlu 1996, Öz and Avcıoğlu 1997, Soya et al. 1996)

Root dry matter yield was affected only by location. The lowest root dry matter yield was achieved from the Ladik location in 2004 and 2005 (6.5 and $6.7 \mathrm{t}$ $\mathrm{ha}^{-1}$, respectively). The highest root dry matter yield was obtained from the Suluova, Bafra, Gümüşhacıköy and Osmancık locations (11.00, 10.7, 10.4 and $10.0 \mathrm{t}$ $\mathrm{ha}^{-1}$, respectively). Fodder beet when grown under suitable conditions, can produce almost $20 \mathrm{t} \mathrm{ha}^{-1}$ dry matter yield (DAF, 1998) compared with $13 \pm 15 \mathrm{t}$ $\mathrm{DM} / \mathrm{ha}^{-1}$ from four harvests of grass.

Sugar content was affected only by location. The highest sugar content was determined in Gümüşhacıköy location (8.8\%) in the first year and in Ladik location $(9.7 \%)$ in the second year. As an average of 2 years, the highest sugar content was obtained from Ladik and Gümüşhacıköy locations (8.9 and $8.6 \%$, respectively).

Our findings are similar to Cox and Atkins (1979) who reported that temperature difference increases by increasing altitude and this increases the sugar rate. Tayşi and Demir, (1979) reported that there was a negative correlation between sugar content and root yield, whereas root dry matter rate is positively correlated with sugar content. Our results are similar to Tayşi and Demir (1979) Year and location effects were significant for root length. The lowest root length was measured in Ladik location $(16.8$ and $14.8 \mathrm{~cm}$, respectively) in both years. As an average of 2 years, the highest root length was measured in Bafra location $(23.2 \mathrm{~cm})$

Root diameter was affected only by location. The highest root diameter was measured in Gümüşhacıköy location in 2004 and $2005(11.0$ and $10.7 \mathrm{~cm}$, respectively). As an average of both years, while the highest root diameter was measured in Gümüşhacıköy $(10.9 \mathrm{~cm})$ location, the lowest root diameter was measured in Osmancık $(8.1 \mathrm{~cm})$ and Ladik $(7.6 \mathrm{~cm})$ locations. It can be said that the factors affecting the root height affect the root diameter as well. Albayrak and Çamaş (2005) found the root diameter $11.1 \mathrm{~cm}$ in fodder beet.

\section{Conclusion}

This study conducted at 5 different locations (Bafra, Ladik, Suluova, Gümüşhacıköy and Osmacık) in Middle Blacksea Region conditions. The highest root and leaf yields were obtained from Bafra and Osmancık locations, while the highest root dry matter content was determined in Ladik, Gümüşhacıköy and Suluova locations, there were not differences among locations except Ladik in dry matter yield. Ladik and Gümüşhacıköy locations had the highest sugar content. Bafra, Suluova, Gümüşhacıköy and Osmacık locations were determined as suitable locations for fodder beet growing for forage production.

\section{References}

Adıyaman, M. 1996. Hayvan Pancarı. Pan tohum geliştirme ve üretim şirketi. Mithatpaşa caddesi. No: 19/2. PK.19, Yenişehir, Ankara.

Albayrak, S and N. Çamaş, 2005. Influence of row spacing on root yield and yield components of fodder beet (Beta vulgaris var. crassa Mansf.) in the Black Sea Coastal Region. Ankara Üniv. Ziraat Fak. Tarım Bilimleri Dergisi. 11: 160-164.

Anonymous, 2006. Fodder beet. http://www.seed2grow.co. uk/acatalog/Fodder_Beet_Seed.html. (16.01.2006).

Avcıoğlu, R., H. Geren, Y. Elmalı ve O. Erekul, 1999. Hayvan pancarı'ında (Beta vulgaris var. rapacea Koch.) farklı ekim zamanı ve bitki yoğunluğunun verim ve bazı verim öğeleri üzerine etkilerinin belirlenmesi üzerine araştırmalar. Türkiye 3. Tarla Bitkileri Kongresi, 113118.

Buryakov, A. T. 1994. A screw-type cleaner for fodder beet. Zemledelie. No: 3, 27. Russia.

Cenais, V. 1994. Use of fodder beet in the feeding of dairy cows. Bulletin des G.T.V. No 2: 49-56. France.

Cox. G. W and M.d. Atkins, 1979. Agricultural Ecology. W.M. Freeman and Company, San Francisco.

DAF (Department of Agriculture and Food), 1998. Root, fodder crop, pulse and oilseed varieties. Irish recommended list. Government Stationary Office, Dublin, $17 \mathrm{p}$.

Drashkov, N. 1996. Results of purfied sofia waste waters in fodder beet irrigation. Pochvoznanie, Agrokhimiia ekologiya, 31: 36-39, Bulgaria.

Geren, H. ve R. Avcıoğlu. 1996. Farklı hayvan pancarı (Beta vulgaris var. rapacea Koch.) çeşitlerinde farklı ekim zamanlarının verim ve verim komponentleri üzerine etkileri. Ege Univ. Yüksek lisans Tezi. 70s.

Grzes, S., S. Sobiech, T. Maciejewski and J. Szukula, 1996. Yield od fodder beet as influenced by sprinkler irrigation, method of sowing the preceeding crop and nitrogen fertilizer application. Prace Zakresu Nauk Rolniczych. 81: 87-94. Poland.

JuSam, L., A. JongHo, J. IkHwan, R. ZinSik, S. ByoungDon, P. MooKyun, J. H. Ahn, I. H. Jo, Z. S. Rho, B. D. Sang and M. K. Park, 1995. Effect of sowing date on the fresh yield of fodder beet cultivars. Journal of the Korean Society of Grassland Science, 15: 140-145. 

the middle black sea region conditions"

Koszanski, Z., S. Karczmarczyk and M. Roy, 1995. Effect of sprinkler irrigation and nitrogen fertilizer application on sugar an fodder beets cultivated on a good rye complex soil. I. Yields. Zeszyty Naukowe Akademii Rolniczej w Szczecinie, Rolnictwo. 59: 57-64. Poland.

Langer, R. H. and G. H. Hill, 1991. Agricultural plants. Plant Science Department, Lincoln Univ, New Zealand, Cambridge Univ. Press.

Lukic, D. and S. Vasilijevic, 1996. Production characteristics of some domestic and foregin fodder beet cultivars. Selekcija i Semenarstvo. 3 (3-4): 86-91 Yugoslavia.

Naescu, V. 2001. The irrigation influence in fodder beet under Fundulea conditions. Analele Institutului de Cercetari pentru Cereale si Plante Tehnice, Fundulea 68 : 301305.

Öz, F. ve R. Avcıŏlu, 1997. Hayvan pancarı (Beta vulgaris var. rapacea Koch.)'ında ekim oranı ve farklı yükseltilerin verim ve bazı verim ögeleri üzerine etkileri. Ege Univ. Yüksek Lisans Tezi.

Özen, N., A. Çakır, S. Haşimoğlu ve S. Aksoy, 1993. Yemler Bilgisi ve Yem Teknolojisi Ders Notları: 50. Atatürk Univ Erzurum.

Podstawka, E. and S. Ceglarek, 1995. Cultivation of sugarbeet and fodder beet on light soil under conditions of sprinkler irrigation and differentiated nitrogen fertilizer application. Annales Universitatis Mariae Curie Sklodowska. Sectio E, Agricultura, 50: 21-27.
Rzekanowski, C. 1994. The reaction of fodder beet grown on very ligth soil so sprinkler irrigation and nitrogen fertilizer application. Roczniki Nauk Rolniczych. Seria F, melioracji i Uzytkow Zielonych,. 83 (3-4) 57-62.

SAS, SAS/STAT 1998. User's Guide.Version 7.0. SAS Institute, Inc.Cary. NC.USA.

Soya, H., R. Avcıoğlu, H. Geren, F. Öz ve A. Öz, 1999. Hayvan pancarı (Beta vulgaris var. rapacea Koch.)'Inda farklı yüksekliklerde ekim zamanı ve ekim oranının verim ve verim komponentleri üzerine etkileri. Türkiye 2 . Tarla Bitkileri Kongresi. 284-288.

Soya, H., R. Avcıoğlu ve H. Geren, 1996. Yembitkileri. Hasat Yayınları. P.K. 212. Kadıköy-Istanbul.

Stroller, J. 1994. Stand structure and yields of fodder beet grown without manual work. Sbornik Vysoke Zemedelske $\vee$ Praze, Fakulta Agronomicka, Rada A, Rostlinna Vyroba. 56: 99-102. Czech Republic.

Tayşi, V. ve I. Demir, 1979. Diploid ve Polyploid Hayvan Pancarının Islahı. Ege Üniv. Ziraat Fak. Yayınları. 51s.

\section{İletişim adresi:}

Sebahattin ALBAYRAK

Süleyman Demirel Univ. Faculty of Agriculture

Department of Agronomy -Isparta

Tel: 02462114630

E-mail: albayrak@ziraat.sdu.edu.tr 
